\title{
Adventitial Pericyte Progenitor/Mesenchymal Stem Cells Participate in the Restenotic Response to Arterial Injury
}

\author{
Ulrich Tigges $^{a}$ Masanobu Komatsu $^{b}$ William B. Stallcup ${ }^{a}$

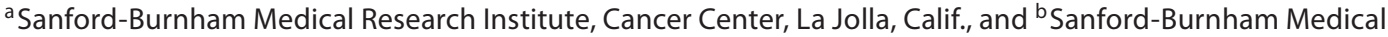 \\ Research Institute at Lake Nona, Orlando, Fla., USA
}

\section{Key Words}

Adventitia $\cdot$ Coronary angioplasty $\cdot$ Mesenchymal stem

cells $\cdot$ Pericyte-like cells $\cdot$ Pericytes $\cdot$ Restenosis arterial injury. These cells are different from myofibroblasts, smooth muscle cells, and other progenitor populations that have been shown to participate in the restenotic process.

Copyright $\odot 2012$ S. Karger AG, Basel

\begin{abstract}
Restenosis is a major complication of coronary angioplasty, at least partly due to the fact that the origin and identity of contributing cell types are not well understood. In this study, we have investigated whether pericyte-like cells or mesenchymal stem cells (MSCs) from the adventitia contribute to restenosis. We demonstrate that while cells expressing the pericyte markers NG2, platelet-derived growth factor receptor $\beta$, and CD146 are rare in the adventitia of uninjured mouse femoral arteries, following injury their numbers strongly increase. Some of these adventitial pericyte-like cells acquire a more MSC-like phenotype (CD90+ and CD29+ are up-regulated) and also appear in the restenotic neointima. Via bone marrow transplantation and ex vivo artery culture approaches, we demonstrate that the pericyte-like MSCs of the injured femoral artery are not derived from the bone marrow, but originate in the adventitia itself mainly via the proliferation of resident pericyte-like cells. In summary, we have identified a population of resident adventitial pericyte-like cells or MSCs that contribute to restenosis following
\end{abstract}

\section{Introduction}

Restenosis has been called the Achilles' heel of coronary angioplasty, since constriction of the vascular lumen in surgically opened arteries is a major factor in compromising the success of coronary artery interventions. Although surgical improvements, including stent technology, have somewhat improved the situation, restenosis remains a pressing clinical challenge [1]. A better understanding of the molecular and cellular mechanisms underlying restenosis will be required to allow further progress in alleviating the problem.

One issue of significance is the identity and origin of cells that contribute to the formation and growth of restenotic lesions. Smooth muscle cells are among the most prominent cellular components of these lesions. Traditional views have maintained that these cells arise exclusively from the media of affected arteries [2]. However, research during the past decade demonstrates that the

\section{KARGER}

Fax +4161306 1234

E-Mail karger@karger.ch

www.karger.com (c) 2012 S. Karger AG, Basel

$1018-1172 / 13 / 0502-0134 \$ 38.00 / 0$

Accessible online at:

www.karger.com/jvr
Dr. Ulrich Tigges

Sanford-Burnham Medical Research Institute, Cancer Center

10901 North Torrey Pines Road

La Jolla, CA 92037 (USA)

E-Mail utigges@gmail.com 
origins of restenotic cells are more varied and complex than previously suspected [3]. For example, bone marrow progenitor cells are reported to differentiate into smooth muscle cells in atherosclerotic lesions and in the neointima of restenotic arteries [4], with bone marrow contribution to neointima formation varying in proportion to the severity of the lesion [5].

Another potential source of progenitor cells during restenosis is the adventitia. Previously thought to be relatively inert, this outermost layer of the arterial wall has now been shown to be a source of cells that can migrate into the lumen of injured arteries and contribute to neointima formation [6-8]. The identity of adventitial progenitor cells that contribute to neointima formation remains uncertain. While earlier reports suggested that adventitial fibroblasts might differentiate into myofibroblasts and migrate into the lumen of injured arteries [9], more recent studies have focused on adventitial cells expressing progenitor markers such as Scal, c-kit, CD133, CD34, and Flk1. For example, adventitial cells expressing Scal have the capability to differentiate into smooth muscle cells both in vitro and in vivo [10].

Further confirmation of the cellular complexity of the restenotic response suggested by these disparate viewpoints is provided by our current work demonstrating the presence of numerous pericyte-like cells (henceforth called pericytes for simplicity) in the restenotic femoral artery. By definition, pericytes are the microvascular counterparts of smooth muscle cells in larger vessels, partnering with vascular endothelial cells during vessel development, maturation, and maintenance. However, in addition to their role as perivascular support cells, a subgroup(s) of pericytes is increasingly regarded as mesenchymal stem cells (MSCs) [11]. Pericytes exhibit tremendous plasticity not only in their developmental origins, but also in their differentiation potential. Developmentally, pericytes can arise not only from stem cell sources such as the bone marrow, but also from cells that reside in mature tissues such as adipose deposits, and both skeletal and smooth muscles [12-18]. The stem cell nature of pericytes is highlighted by several recent papers demonstrating the ability of pericytes to give rise to a variety of mesenchymal cell types in different organs, including skeletal muscle, smooth muscle, bone, cartilage, and adipose tissue [19-24]. Moreover, adventitial pericytes have been implicated in pathological processes such as wound healing and arterial calcification [25-27]. Pericytes therefore possess several of the properties associated with stem cells or adventitial progenitors that may participate in restenosis. In this communication, our goals have been to characterize some of the properties of adventitial pericytes and to provide additional evidence for the contribution of these cells to neointima formation during restenosis.

\section{Materials and Methods}

\section{Antibodies}

Rabbit polyclonal antibodies against NG2 and platelet-derived growth factor receptor (PDGFR) $\beta$ and guinea pig polyclonal antibody against NG2 have been described previously [28, 29]. Rat monoclonal F4/80 antibody was purchased from BioSource International (Camarillo, Calif., USA), and rabbit polyclonal CD146 antibody from Abcam (Cambridge, Mass., USA). Rat monoclonal antibodies against Sca1, CD11b, CD29, CD31, CD44, CD45, CD71, CD73, and CD90 were from BD Biosciences (La Jolla, Calif., USA). Cy3-coupled $\alpha$-smooth muscle actin (SMA) antibody was purchased from Sigma (St. Louis, Mo., USA). 5-Bromo-2'-deoxyuridine (BrdU) antibody was from Serotec. Cy5-conjugated secondary antibody was obtained from Jackson ImmunoResearch (West Grove, Pa., USA). Alexa 488- and Alexa 568-conjugated secondary antibodies were purchased from Molecular Probes (Eugene, Oreg., USA).

\section{Animals}

Adult, male, 8 - to 12 -week-old $\mathrm{C} 57 \mathrm{Bl} / 6$ mice and $\mathrm{C} 57 \mathrm{Bl} / 6$ mice expressing enhanced green fluorescent protein (EGFP) under control of the $\beta$-actin promoter ( $\beta$-actin/EGFP; Jackson Laboratories) were used. Mice were maintained in the Sanford-Burnham Vivarium (fully accredited by the Association for Assessment and Accreditation of Laboratory Animal Care). All animal procedures were performed in accordance with Office of Laboratory Animal Welfare regulations and were approved by Sanford-Burnham Animal Care and Use Committee review prior to execution.

\section{Femoral Artery Injury Model}

Femoral artery injuries were performed as previously described $[4,30]$. Briefly, the left femoral artery was exposed by blunt dissection. After careful separation of the femoral nerve, both the femoral artery and vein were looped together proximally and distally with silk sutures for temporary vascular control. A small branch between the rectus femoris and the vastus medialis muscle was separated, proximally looped, and distally ligated with 4-0 sutures. The artery was then further separated from surrounding veins and connective tissue. After dilating the exposed artery with one drop of $1 \%$ lidocaine hydrochloride, a small incision was made into the muscular branch artery with Vannas style iris spring scissors and a spring wire $(0.38 \mathrm{~mm}$ in diameter, No. C-SF-15-15; Cook, Bloomington, Ind., USA) was carefully inserted to a depth of approximately $8 \mathrm{~mm}$ toward the iliac artery. The wire was left in place for $1 \mathrm{~min}$, to denude and dilate the artery, and then removed. The suture looped at the proximal side of the muscular branch artery was secured, blood flow was restored, and the skin incision was closed with sutures. In some cases, BrdU (80 $\mathrm{mg} / \mathrm{kg}$ ) was injected 3 and 4 days after femoral artery injury. At specified time points, mice were euthanized by $\mathrm{CO}_{2}$ asphyxiation. Both the left and the right femoral artery were excised (the right artery as a control), fixed in $4 \%$ paraformaldehyde, cryoprotected 
overnight in $20 \%$ (wt/vol) sucrose/phosphate-buffered saline (PBS) and frozen in OCT embedding compound (Tissue-Tek). Sections $(25 \mu \mathrm{m})$ were prepared using a Reichert cryostat microtome.

\section{Bone Marrow Transplantation}

Bone marrow transplantations were performed as previously described [17]. One $\beta$-actin/EGFP donor mouse per transplantation was euthanized by $\mathrm{CO}_{2}$ asphyxiation. Femurs and tibiae were dissected, and the bone marrow was flushed out with $1 \mathrm{ml}$ of PBS containing $2 \%$ fetal calf serum (FCS) and $5 \mathrm{mM}$ EDTA (PBS/FCS/ EDTA). The bone marrow cells were washed once with PBS/FCS/ EDTA, and subsequently red blood cells were lysed on ice for 5 min with ACK buffer $\left(150 \mathrm{mM} \mathrm{NH}_{4} \mathrm{Cl}, 10 \mathrm{mM} \mathrm{KHCO}_{3}, 0.1 \mathrm{mM}\right.$ EDTA, pH 7.4). After the lysis step, cells were washed twice with PBS/FCS/EDTA. Between 5 and $7 \times 10^{7}$ cells were typically collected from a single donor. Immediately before injection into recipient mice, cells were passed through a $62-\mu \mathrm{m}$ nylon filter (Small Parts, Miami Lakes, Fla., USA) and washed once with Ringer's solution. Recipient mice were $\gamma$-irradiated (two 5-Gy doses administered $3 \mathrm{~h}$ apart) using a ${ }^{137} \mathrm{Cs}$ Gammacell-40 Exactor irradiator. Animals were immediately reconstituted via retroorbital injection of $6 \times 10^{5}$ bone marrow cells in $100 \mu$ l of Ringer's solution and were maintained on antibiotic water (neomycin sulfate, $1.1 \mathrm{~g} / \mathrm{l}$ and polymyxin B sulfate, $455 \mathrm{mg} / \mathrm{l}$ ) for 6 weeks to allow hematopoietic re-establishment. Retro-orbital blood samples were taken from each recipient, and the extent of EGFP engraftment was determined by flow-cytometric analysis. Animals exhibiting at least $75 \%$ engraftment were used for femoral artery injury experiments.

\section{Immunostaining and Confocal Microscopy}

Immunostaining and confocal microscopy were performed as previously described $[28,29]$. An inverted Radiance 2100 multiphoton confocal microscope (BioRad, Hercules, Calif., USA) was used to obtain serial 1- to 1.5 - $\mu \mathrm{m}$ optical sections across the entire $25-\mu \mathrm{m}$ thickness of the histological specimens. This confocal system provides for analysis of four fluorochromes, allowing us to perform quadruple labeling with DAPI and 3 antibodies, or with DAPI, 3 antibodies, and the EGFP transgene. Overlaid serial optical sections ( $z$-stacks) were analyzed using Volocity 4D Rendering software (version 3.7) for unambiguous determination of the spatial relationship between cells. Differences between marker expression in the adventitia or neointima are determined either by analysis and counting of individual cells or by measurement of signal intensity with Volocity software on sections labeled and scanned under standardized conditions.

\section{Ex vivo Aortic Explants}

Thoracic aortas were isolated from wild-type $\mathrm{C} 57 \mathrm{Bl} / 6$ mice and 3-mm pieces were maintained free-floating for 6 days at $37^{\circ} \mathrm{C}$ and $5 \% \mathrm{CO}_{2}$ in a cell culture dish containing DMEM, DMEM with $10 \%$ FCS, DMEM with 50 ng/ml PDGF-BB, or MSC expansion medium (MSCEM; Gibco). When indicated, $10 \mu \mathrm{M}$ BrdU were added to the culture medium for the entire incubation time. After incubation, aortic specimens were fixed with $4 \%$ paraformaldehyde, cryoprotected overnight in 20\% (wt/vol) sucrose/ PBS, and frozen in OCT embedding compound (Tissue-Tek). Sections $(25 \mu \mathrm{m})$ were prepared using a Reichert cryostat microtome. Sections were used for immunostaining and confocal microsco- py, and expression differences between groups were determined by analysis and counting of individual cells with Volocity software.

Statistical Analysis

Unpaired Student's t tests were used to determine if measured differences between data were significant. A value of $p<0.05$ is considered statistically significant. All values represent experiments done at least in triplicate and are given as means \pm SEM.

\section{Results}

\section{A Heterogeneous Population of Pericyte-Like Cells} Expands within the Adventitia of the Injured Femoral Artery

In order to study the distribution and fate of putative progenitor cells within the arterial wall during restenosis, we used a femoral artery injury model $[4,30]$ that consistently resulted in significant medial thickening and formation of a neointima 9-12 days after the injury. We used immunostaining for NG2 and PDGFR $\beta$ to detect the presence of pericytes/MSCs during the process of arterial remodeling after injury. Within the adventitia of healthy, uninjured femoral arteries, cells expressing these pericyte markers are found infrequently (fig. 1a). However, 7 days after injury, the number of NG2-positive cells in the adventitia increases dramatically (fig. 1b), with NG2 expression levels rising more than 7-fold (fig. 1c). A similar increase is observed for PDGFR $\beta$-positive cells in the adventitia (fig. 1b). Confocal co-localization analysis shows that about $40 \%$ of adventitial NG2positive cells also express PDGFR $\beta$ (fig. 1b), demonstrat-

Fig. 1. Pericyte-like cells in the adventitia. Pericyte-like cells expressing both NG2 (green) and PDGFR $\beta$ (red; arrowhead) are found only rarely in the uninjured femoral artery (a). Seven days after femoral artery injury, the pericyte markers PDGFR $\beta$ (red) and NG2 (green) are present on many cells in the adventitia (a). At this time point, the media (m) has undergone apoptosis (b). The increase in NG2 expression 7 days after injury, as determined by quantification of NG2 pixels, is roughly 7-fold (c; $\mathrm{p}=0.001$ ). Relative to NG2 (green), Sca1 (red) expression is relatively high in the adventitia of uninjured femoral arteries (d) and decreases in response to arterial injury $(\mathbf{e}, \mathbf{f} ; \mathbf{p}=0.04)$. NG2-positive pericytes (magenta) in uninjured femoral arteries co-express CD146 (red; arrowhead; h, j) but do not express CD90 (green; arrowhead; i, j). Seven days after femoral artery injury, the expression pattern of adventitial cells changes considerably: NG2+/CD146+ cells are found in higher numbers $(\mathbf{k}-\mathbf{n})$ and populations of cells expressing NG2, CD146, and CD90 (k-n) or NG2, CD90, and CD29 (o-r) can be detected. Blue $=$ DAPI. Scale bars: $40 \mu \mathrm{m}$. 

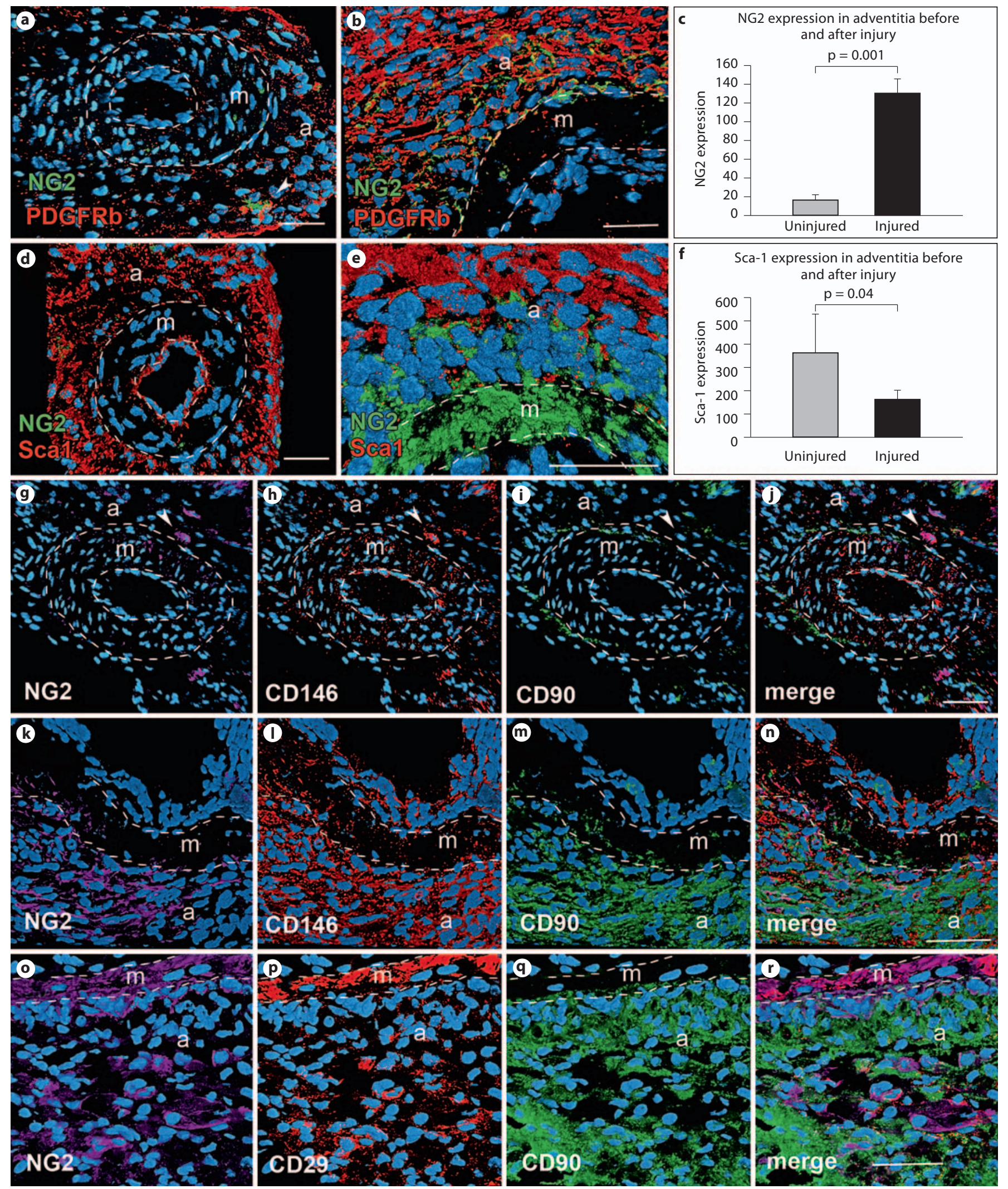
ing that pericytes of the femoral artery may be a heterogeneous population, as has been suggested for pericytes in general [31].

In some tissues, pericytes are thought to be progenitors of myofibroblasts [32], a cell type proposed to contribute to restenosis [6]. However, we failed to detect the myofibroblast marker $\alpha$-SMA [33,34] in the injured adventitia. Similarly, a restenotic contribution has been suggested for adventitial Scal-positive cells [10]. However, the behavior of Sca1-positive cells in the femoral artery injury model is distinct from that of NG2-/PDGFR $\beta$-positive pericytes. Sca1-positive cells are already numerous in the adventitia of the uninjured femoral artery, and Sca1 levels decrease after injury (fig. 1d-f). Moreover, there is little or no overlap between Scal and NG2/ PDGFR $\beta$ expression. Indeed, these two cell populations occupy different zones of the adventitia. NG2-/PDGFR $\beta$ positive pericytes are found almost exclusively near the boundary between the adventitia and media, while Sca1positive progenitors occupy a more superficial layer of the adventitia. It has been suggested that the adventitial layer adjacent to the media is a vasculogenic zone that harbors progenitor cells [35].

In light of numerous reports identifying pericytes as MSCs, we aimed to determine whether NG2-positive adventitial cells express other markers associated with MSCs, such as CD29, CD44, CD71, CD73, CD90, or CD146 [11, 20]. Although abundant, CD44-positive cells do not co-express NG2, and cells expressing CD71 or CD73 are not detected in either healthy or injured arteries (table 1). The rare NG2-positive cells in the adventitia of the uninjured femoral artery are positive for CD146

Table 1. Expression of pericyte and MSC markers in femoral arteries (FA) before and after injury

\begin{tabular}{|c|c|c|c|c|c|}
\hline & $\begin{array}{l}\text { Uninjured } \\
\text { adventitia } \\
\text { FA }\end{array}$ & $\begin{array}{l}\text { Injured } \\
\text { adventi- } \\
\text { tia FA }\end{array}$ & $\begin{array}{l}\text { Co-expres- } \\
\text { sion with } \\
\text { NG2 (inj. } \\
\text { adv. FA) }\end{array}$ & $\begin{array}{l}\text { Injured } \\
\text { neointima } \\
\text { FA }\end{array}$ & $\begin{array}{l}\text { Co-expres- } \\
\text { sion with } \\
\text { NG2 (inj. } \\
\text { neo. FA) }\end{array}$ \\
\hline CD29 & - & + & + & + & + \\
\hline CD44 & - & + & - & - & - \\
\hline CD71 & - & - & - & - & - \\
\hline CD73 & - & - & - & - & - \\
\hline CD90 & $+($ few cells $)$ & + & + & + & + \\
\hline CD146 & $+($ few cells $)$ & + & + & + & + \\
\hline NG2 & $+($ few cells $)$ & + & + & + & + \\
\hline PDGFR $\beta$ & + & + & + & + & + \\
\hline Scal & + & + & - & $+($ few cells $)$ & - \\
\hline
\end{tabular}

expression, consistent with published observations that CD146 is expressed by both pericytes and MSCs [36, 37]. None of the other MSC markers are expressed by NG2positive cells in the healthy adventitia (fig. $1 \mathrm{~g}-\mathrm{j}, 2 \mathrm{e}$; table 1). However, following injury, the phenotype of NG2positive cells becomes more complex, with CD90, CD29, and CD146 all being co-expressed to varying extents by NG2-positive cells (fig. 1k-r). Figure 1e, p illustrates a phenomenon that is sometimes observed for NG2 and CD29 immunostaining in this injury model; namely, an abundance of labeling in the apoptotic media. This is also seen in figure $10, r$ and figure $2 \mathrm{a}, \mathrm{f}, \mathrm{h}$. While we have speculated that this might represent binding of NG2 and $\beta_{1}$-integrins to extracellular matrix material remaining after smooth muscle cell apoptosis, this has not been confirmed. Since this medial labeling is inconsistent and not understood, we have not included it in our analyses.

In accord with the idea that pericytes do not express hematopoietic, myeloid, or endothelial markers, NG2 is not expressed on CD31-positive (endothelial) or CD11bpositive (myeloid) cells either in uninjured or injured femoral arteries (data not shown). Also, fewer than $1 \%$ of NG2-positive cells in the injured artery express the hematopoietic marker CD45 (fig. 2a). In contrast to pericytes,

Fig. 2. Pericyte-like cells in the neointima. CD29 is not expressed in the uninjured femoral adventitia (e) but is found co-expressed (red) with NG2 (green) in the adventitia of injured femoral arteries (7 days after injury; h). The hematopoietic marker CD45 (red) is rarely co-expressed on NG2+ cells (green; $<1 \%$ ) in a superficial layer of the injured adventitia (arrowhead; 7 days after injury; a). Fifteen days after femoral artery injury, formation of a neointima (ni) can be observed (b, c, i-t). Although abundant on cells in the adventitia (a), Scal is only occasionally found on cells on the luminal surface of the neointima $(\mathbf{b}, \mathbf{j}, \mathbf{I})$. NG2 is expressed on many cells throughout the neointima (c). Double labeling for NG2 (green) and $\alpha$-SMA (red; c, d) reveals all possible combinations of staining: NG2-positive, SMA-positive (arrowhead in c); NG2positive, SMA-negative (arrows in c); NG2-negative, SMA-positive, and NG2-negative, SMA-negative staining. At 15 days after injury, the neointima also contains cells co-expressing NG2 (magenta), CD90 (green), and CD146 (red; arrowheads; $\mathbf{m}-\mathbf{p}$ ) or NG2 (magenta), CD90 (green), and CD29 (red; q-t). Bone marrow transplantation experiments using $\beta$-actin/EGFP donors reveal that 7 days after femoral artery injury, the adventitia contains almost no EGFP+ cells (green) co-expressing NG2 (magenta; f) or Scal (red; g). The same is true of the neointima 15 days after injury (i-I). These findings suggest that NG2- and Sca1-positive adventitial progenitor cells that contribute to restenosis are not derived from the bone marrow. Blue $=$ DAPI; aSMA $=\alpha$-SMA. Scale bars: $40 \mu \mathrm{m}$. 

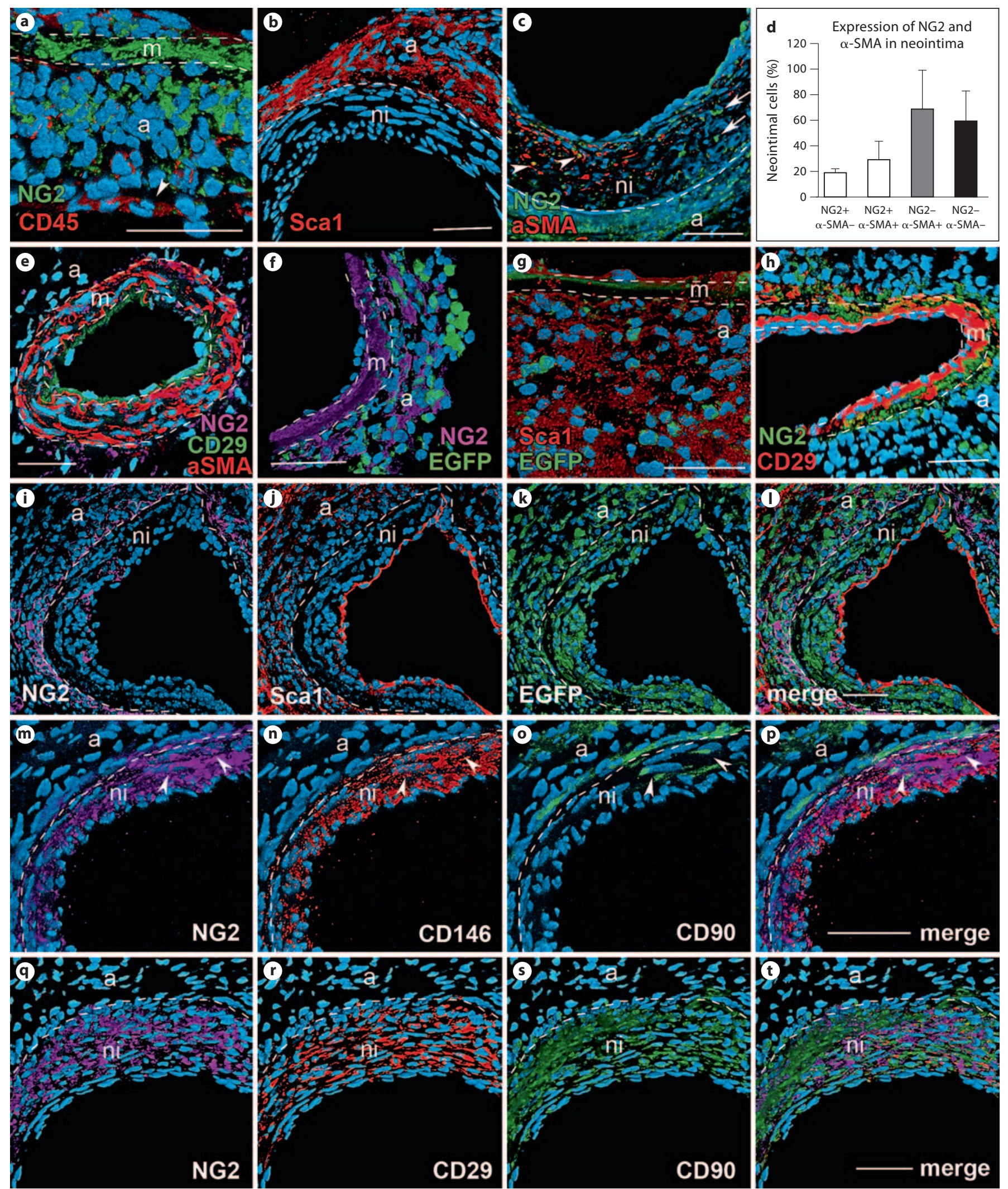
these rare NG2-positive/CD45-positive cells are always found in more superficial regions of the adventitia rather than in the region directly adjacent to the media. We also used the pan-macrophage marker F4/80 to further evaluate possible myeloid expression of NG2 7 days after injury. Although NG2 is known to be transiently expressed by macrophages in some models $[17,38]$, and although F4/80-positive macrophages are present in the adventitia of injured arteries, we did not detect co-expression of NG2 and F4/80 (data not shown).

NG2+, CD90+, CD146+, CD29+ Cells Also Appear in the Neointima of Femoral Arteries after Injury

To investigate whether cells expressing pericyte markers contribute to neointima formation, we used immunostaining to examine injured femoral arteries at later time points (9-30 days after injury). At 15 days after injury, Scal is rarely expressed by neointimal cells (fig. 2b), and Scal-positive cells are only occasionally seen at the luminal surface of the neointima (fig. 2j, 1). In contrast, NG2 is expressed 15 days after injury by many cells throughout the neointima (fig. 2c), some of which are also positive for $\alpha$-SMA (fig. 2c, d). This is consistent with the fact that NG2 is known to be expressed by developing vascular smooth muscle cells, although the proteoglycan is usually down-regulated with differentiation $[28,39]$. Interestingly, we found that CD29, CD90, and CD146 are expressed by NG2-positive cells in the neointima (fig. $2 \mathrm{~m}-$ $\mathrm{t}$ ), echoing the situation encountered in the adventitia. Since CD29, CD90 and CD146 are not expressed by smooth muscle cells in the femoral artery (fig. 1g-j, 2e), these findings are in accord with the idea that pericytes from the adventitia might contribute to neointima formation after arterial injury. In addition to neointimal smooth muscle cells that co-express NG2 and $\alpha$-SMA and more mature smooth muscle cells that are $\alpha$-SMA positive and NG2-negative, we also identified a population of NG2-positive cells that do not express $\alpha$-SMA (fig. 2c, d). These NG2-positive, $\alpha$-SMA-negative cells could represent pericytes prior to their differentiation to smooth muscle cells.

\section{Adventitial Progenitor Cells Are Not Derived from the Bone Marrow}

In order to determine if adventitial pericytes are derived from the bone marrow following femoral artery injury, we irradiated C57Bl/6 wild-type mice and reconstituted them with bone marrow cells from $\beta$-actin/EGFP transgenic mice. Six weeks after transplantation, we used these mice in the femoral artery injury model. It is known that the contribution of bone marrow cells during restenosis is high in cases of severe arterial damage, such as the femoral artery injury model, while mild arterial injury induces little or no contribution from the bone marrow [5]. Consistent with this trend, we observed a very large number of bone marrow-derived cells in the restenotic femoral artery. These EGFP-tagged cells are present initially in the adventitia ( 7 days after injury) and later in the neointima (after 15 days; fig. 2f, g, k, l). Many of these cells are positive for $\mathrm{F} 4 / 80$, consistent with their identity as myeloid cells. Surprisingly, however, NG2- and Sca1positive cells in the adventitia rarely express EGFP, showing that neither of these adventitial progenitor populations has a significant degree of origin from the bone marrow (fig. $2 \mathrm{f}, \mathrm{g}$ ). Comparable findings were made in the neointima. Careful analysis of confocal images revealed almost no co-expression of NG2 or Sca1 with the EGFP tracer (fig. 2i-1). Although co-expression of EGFP with NG2 or Sca1 could not be ruled out in a small number of cases (about 3\% of the EGFP-positive cells), overall our data reveal that NG2-positive and Sca1-positive progenitor cells in the adventitia and neointima of femoral arteries are mostly derived from non-bone marrow sources.

Increased Adventitial NG2 Expression due to Both Up-Regulation of NG2 Expression and Expansion of NG2-Positive Progenitor Cells

Since the bone marrow transplantation experiments show that few NG2-positive cells are recruited to the injured artery from the bone marrow, NG2-positive cells must arise locally. These cells might arise either by upregulation of NG2 expression in cells that were previously NG2 negative or else by proliferation of rare NG2-positive pericytes in the adventitia. Shi et al. [6] previously used a porcine coronary artery model to show that adventitial cells exhibit high levels of mitotic activity following injury. By administering BrdU 3 and 4 days following femoral artery injury, we also found that many adventitial cell are mitotic, including some cells expressing NG2 (data not shown). This suggests that at least part of the increase in NG2-positive adventitial cells after injury is due to cell proliferation. In order to more directly address the possibility of NG2 up-regulation in a way that excludes invading cells from other tissues, we turned to a cell culture model that allowed us to examine both cell proliferation and NG2 expression.

Our attempts to utilize the femoral artery for these cell culture experiments were frustrated by extreme variability in the viability of explants. In contrast, we 
Fig. 3. Up-regulation of NG2 expression. When segments of the thoracic aorta are incubated for 6 days in DMEM supplemented with $10 \%$ FCS (b, d), DMEM supplemented with $50 \mathrm{ng} / \mathrm{ml}$ PDGF-BB (c, d), or MSCEM (d), many NG2-expressing cells (green) appear in the adventitia (a). Aortic explants incubated in DMEM for 6 days without any supplements contain few, if any, NG2-expressing adventitial cells (a, d). $\mathrm{p}$ values (d) represent statistically significant differences between untreated and treated aortic segments, and between MSC-treated and PDGF-BB-treated segments. Unlike smooth muscle cells of the femoral artery, which are mostly NG2negative, $\alpha$-SMA-positive smooth muscle cells (red) of the aortic media express high levels of NG2 (a-c). However, NG2-positive cells in the adventitia never express $\alpha$ SMA (a-c), suggesting that adventitial NG2-positive cells in this experiment are not derived from the aortic media (m). When aortic explants are incubated with BrdU for 6 days in DMEM supplemented with PDGF-BB, BrdU (red) is incorporated into virtually all aortic NG2-positive cells (green; arrowheads; e). However, incubation of explants with BrdU for 6 days in MSCEM leads to a mixed population of mitotic (BrdU-positive, arrowheads) and non-mitotic (BrdU-negative, arrows) NG2-positive cells (f), providing evidence that NG2 expression by adventitial cells can increase not only via mitosis, but also via up-regulation. Blue = DAPI; aSMA = $\alpha$-SMA. Scale bar: $40 \mu \mathrm{m}$.
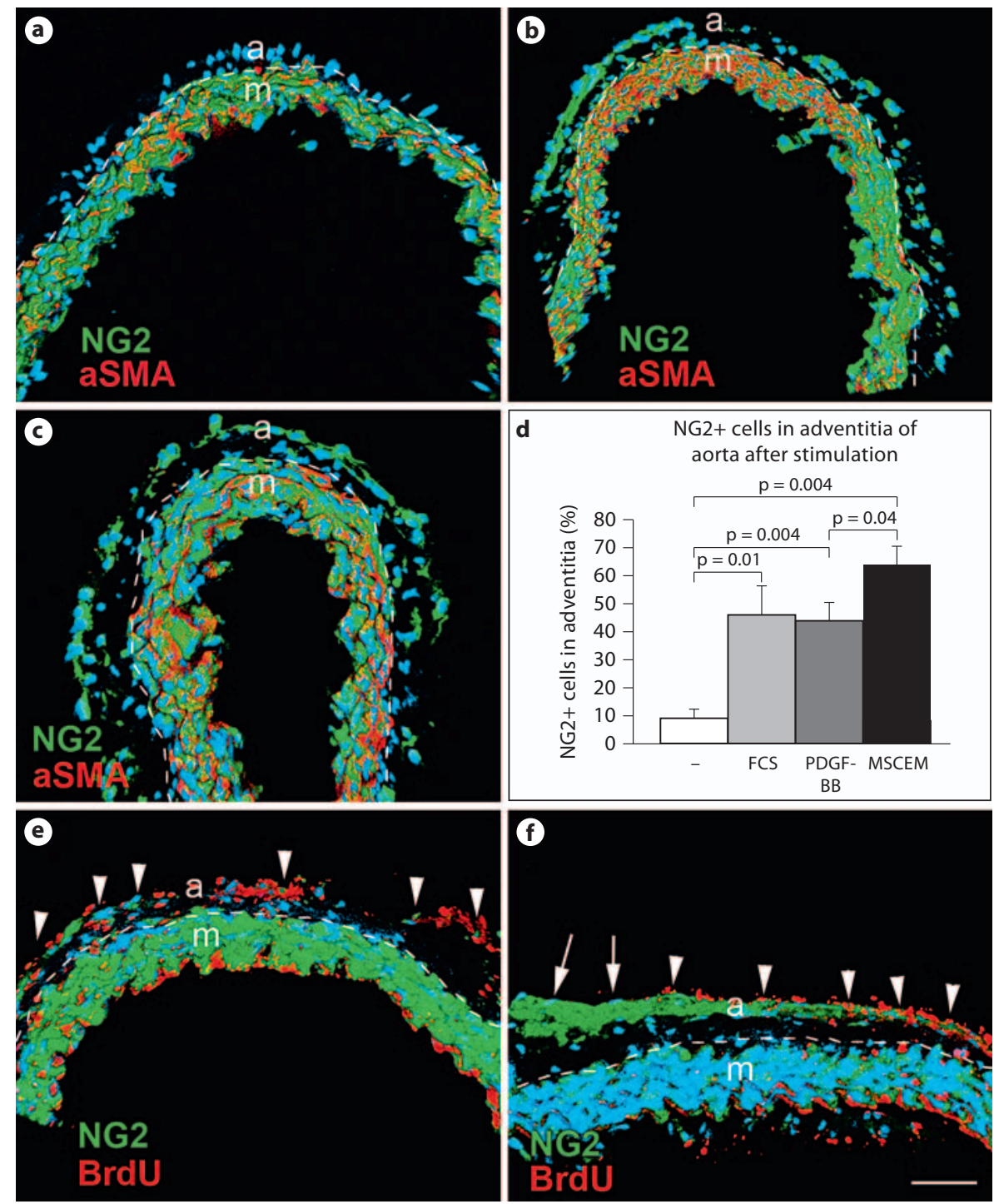

were successful in reproducibly culturing dissected thoracic aortas from wild-type $\mathrm{C} 57 \mathrm{Bl} / 6$ mice. We therefore used this model to obtain additional information concerning pericyte proliferation versus NG2 up-regulation. As in the adventitia of femoral arteries in situ, NG2 is only rarely found on aortic adventitial cells at the time of dissection or after 6 days in non-supplemented DMEM (fig. 3a, d). However, a large number of NG2positive cells are present in the adventitia of the FCSstimulated thoracic aortas (fig. 3b, d). A similar increase in adventitial NG2-positive cells is seen following stimulation of the explants with $50 \mathrm{ng} / \mathrm{ml}$ PDGF-BB (fig. 3c, d), an important factor for pericyte recruitment [40, 41]. In both of these latter cases, cell numbers in the outer adventitial layer are increased by over 50\% during the 6 -day culture period, indicating that stimulation with either FCS or PDGF-BB might cause extensive cell proliferation or recruitment. Determination of BrdU incorporation into these cultures showed that, in the presence of either PDGF-BB or FCS, virtually all adventitial NG2positive cells had incorporated BrdU and were therefore mitotic (fig. 3e). In contrast, when we used optimized MSCEM for the cultures, aortas contained higher numbers of NG2-positive adventitial cells than cultures grown with PDGF-BB or FCS (fig. 1d). In this case, we found that about $40 \%$ of NG2-positive cells in the adventitia had not incorporated BrdU (fig. 3f), consistent with the idea that both cell proliferation and NG2 up-regula- 
tion can contribute to the increased abundance of NG2positive cells. Rapid up-regulation of NG2 expression has also been reported in venules in response to vascular remodeling [42].

\section{Discussion}

The arterial wall has been proposed to harbor various types of progenitor and stem cell populations that contribute to both developmental and repair processes [43]. Based on reports that the adventitia provides a perivascular niche for progenitors that contribute to muscle regeneration, vasculogenesis, fibrosis, and atherosclerosis $[6,44-47]$, we have paid special attention to the adventitia in our analysis. Our hypothesis in this work has been that pericytes in the arterial wall might serve as a source of progenitors for vessel repair. Two of the most reliable and widely used markers for pericytes are PDGFR $\beta$ and the NG2 proteoglycan $[17,28,48]$. While the adventitia of uninjured arteries contains very few cells expressing either NG2 or PDGFR $\beta$, there is a 7-fold increase in adventitial pericytes during the early stages of remodeling after the wire injury. These pericytes do not appear to be a homogeneous population, as evidenced by the fact that there is only a $40 \%$ overlap between NG2 and PDGFR $\beta$ labeling.

Other markers indicative of an MSC phenotype (CD90, CD29, and CD146) also exhibit partial overlap with NG2, further underscoring the heterogeneity of adventitial pericyte/MSC populations. It remains to be demonstrated whether heterogeneity in marker expression is mirrored by heterogeneity in functional properties and/or developmental potential. Our experience in this regard echoes previous reports that single markers are not sufficient for the identification of pericytes/MSCs. Instead, a panel of markers is required for characterization of these cells. Double and triple labeling analyses of injured femoral arteries reveal that CD29 is almost always expressed on cells that also express NG2 and CD90 (fig. 1o-r). Thus, along with NG2 and CD146 in uninjured arteries, the NG2-CD90-CD29 combination has been the most useful set of markers in our hands for studying pericytes in the arterial injury model (fig. $1 \mathrm{k}-\mathrm{r}$ ). Interestingly, of the MSC markers tested, CD29 ( $\beta_{1}$-integrin) expression is most tightly linked with that of NG2. Since NG2 interacts physically with $\beta_{1}$-integrins and enhances $\beta_{1}$-integrin signaling to promote cell proliferation, motility, and apoptosis resistance [49-51], it is tempting to speculate that $N G 2-/ \beta_{1}$-integrin-dependent signaling could be important for some aspect of pericyte/ MSC expansion and/or recruitment.

As arterial remodeling progresses, NG2-positive cells are also detected in the neointima. As in the adventitia, these NG2-positive cells also express various combinations of CD29, CD90, and CD146, consistent with the idea that pericytes from the adventitia may participate in the formation of the neointima. The expression of $\alpha$-SMA by some of these NG2-positive cells suggests that adventitial pericytes/MSCs can serve as a source of neointimal smooth muscle cells.

Using a bone marrow transplantation approach, we found abundant bone marrow-derived macrophages in remodeling arteries, but were unable to detect any contribution of bone marrow cells to the generation of pericytes that are seen in the remodeling adventitia and neointima. This stands in vivid contrast to our previous work with neovascularization of FGF2-containing Matrigel plugs, in which we observed substantial bone marrow derivation of pericytes [17]. Other investigators using different types of models have also reported significant recruitment of pericytes from the bone marrow $[13,14]$. It is important to note that bone marrow-derived pericytes/ MSCs (resident MSCs) that occupy the adventitia prior to bone marrow transplantation and subsequent injury are not detected using our methodology.

The results of the bone marrow transplantation studies indicate that the adventitial pericyte population(s) mainly arises via expansion of rare cells in the arterial wall. Experiments with aortic explants support this possibility. NG2-positive cells are rare in the adventitia at the time of dissection, but become numerous 6 days after stimulation with fetal bovine serum, PDGF-BB, or MSCEM. Quantification of BrdU incorporation reveals that cell proliferation is responsible for almost all of this increase in MSC numbers, except in the case when we used MSCEM, which stimulates up-regulation of NG2 expression in addition to cell proliferation.

In summary, we have identified a population of pericyte-like or mesenchymal stem cells that contribute to restenosis following arterial injury. These cells are distinct from myofibroblasts, smooth muscle cells, and other progenitor populations that have been implicated in promoting the restenotic process, but might be related to other vessel wall progenitor cells that have been described as stem cell sources in various tissues [21, 52-54]. Pericyte-like cells are not derived from the bone marrow, but originate in the adventitia itself. The population expands in the adventitia via cell division rather than by recruitment from external sources. As restenosis progresses, the 
pericyte-like cells begin to appear near the vessel lumen, where they give rise to $\alpha$-SMA-positive cells that contribute to the assembly of the neointima. Manipulation of this population may offer one means of controlling restenosis.

\section{Acknowledgments}

We thank Jennifer Santini, Joseph Russo, and Dr. Edward Monosov for assistance with confocal microscopy. This work was supported by NIH grants RO1 CA95287 and PO1 HD25938 to W.B.S., and RO1 CA125255 to M.K., and by an American Heart Association postdoctoral fellowship (0525199Y) to U.T.

\section{References}

1 Lal BK: Recurrent carotid stenosis after CEA and CAS: diagnosis and management. Semin Vasc Surg 2007;20:259-266.

$\longrightarrow 2$ Lange RA, Flores ED, Hillis LD: Restenosis after coronary balloon angioplasty. Annu Rev Med 1991;42:127-132.

-3 Forte A, Cipollaro M, Cascino A, Galderisi U: Pathophysiology of stem cells in restenosis. Histol Histopathol 2007;22:547-557.

-4 Sata M, Maejima Y, Adachi F, Fukino K, Saiura A, Sugiura S, Aoyagi T, Imai Y, Kurihara H, Kimura K, Omata M, Makuuchi M, Hirata Y, Nagai R: A mouse model of vascular injury that induces rapid onset of medial cell apoptosis followed by reproducible neointimal hyperplasia. J Mol Cell Cardiol 2000;32: 2097-2104.

5 Tanaka K, Sata M, Hirata Y, Nagai R: Diverse contribution of bone marrow cells to neointimal hyperplasia after mechanical vascular injuries. Circ Res 2003;93:783-790.

-6 Shi Y, O’Brien JE, Fard A, Mannion JD, Wang D, Zalewski A: Adventitial myofibroblasts contribute to neointimal formation in injured porcine coronary arteries. Circulation 1996;94:1655-1664.

7 Majesky MW, Dong XR, Hoglund V, Mahoney WM Jr, Daum G: The adventitia: a dynamic interface containing resident progenitor cells. Arterioscler Thromb Vasc Biol 2011;31:1530-1539.

8 Majesky MW, Dong XR, Hoglund V, Daum G, Mahoney WM Jr: The adventitia: a progenitor cell niche for the vessel wall. Cells Tissues Organs 2012;195:73-81.

-9 Shi Y, Pieniek M, Fard A, O’Brien J, Mannion JD, Zalewski A: Adventitial remodeling after coronary arterial injury. Circulation 1996; 93:340-348.

10 Hu Y, Zhang Z, Torsney E, Afzal AR, Davison F, Metzler B, Xu Q: Abundant progenitor cells in the adventitia contribute to atherosclerosis of vein grafts in ApoE-deficient mice. J Clin Invest 2004;113:1258-1265.

11 Caplan AI: All MSCs are pericytes? Cell Stem Cell 2008;3:229-230.

-12 Allt G, Lawrenson JG: Pericytes: cell biology and pathology. Cells Tissues Organs 2001; 169:1-11.
13 De Palma M, Venneri MA, Galli R, Sergi Sergi L, Politi LS, Sampaolesi M, Naldini L: Tie2 identifies a hematopoietic lineage of proangiogenic monocytes required for tumor vessel formation and a mesenchymal population of pericyte progenitors. Cancer Cell 2005;8:211-226.

14 Ozerdem U, Alitalo K, Salven P, Li A: Contribution of bone marrow-derived pericyte precursor cells to corneal vasculogenesis. Invest Ophthalmol Vis Sci 2005;46:3502-3506.

15 Rajantie I, Ilmonen M, Alminaite A, Ozerdem U, Alitalo K, Salven P: Adult bone marrow-derived cells recruited during angiogenesis comprise precursors for periendothelial vascular mural cells. Blood 2004;104: 2084-2086.

16 Sims DE: Diversity within pericytes. Clin Exp Pharmacol Physiol 2000;27:842-846.

- 17 Tigges U, Hyer EG, Scharf J, Stallcup WB: FGF2-dependent neovascularization of subcutaneous Matrigel plugs is initiated by bone marrow-derived pericytes and macrophages. Development 2008;135:523-532.

18 Traktuev DO, Merfeld-Clauss S, Li J, Kolonin M, Arap W, Pasqualini R, Johnstone BH, March KL: A population of multipotent CD34-positive adipose stromal cells share pericyte and mesenchymal surface markers, reside in a periendothelial location, and stabilize endothelial networks. Circ Res 2008; 102:77-85.

19 Brachvogel B, Moch H, Pausch F, SchlotzerSchrehardt U, Hofmann C, Hallmann R, von der Mark K, Winkler T, Pöschl E: Perivascular cells expressing annexin A5 define a novel mesenchymal stem cell-like population with the capacity to differentiate into multiple mesenchymal lineages. Development 2005;132:2657-2668.

20 Crisan M, Huard J, Zheng B, Sun B, Yap S, Logar A, Giacobino JP, Casteilla L, Peault B: Purification and culture of human blood vessel-associated progenitor cells. Curr Protoc Stem Cell Biol 2008;2:2B.2.1-2B.2.13.

21 Dellavalle A, Sampaolesi M, Tonlorenzi R, Tagliafico E, Sacchetti B, Perani L, Innocenzi A, Galvez BG, Messina G, Morosetti R, Li S, Belicchi M, Peretti G, Chamberlain JS, Wright WE, Torrente Y, Ferrari S, Bianco P, Cossu G: Pericytes of human skeletal muscle are myogenic precursors distinct from satellite cells. Nat Cell Biol 2007;9:255-267.
22 Doherty MJ, Ashton BA, Walsh S, Beresford JN, Grant ME, Canfield AE: Vascular pericytes express osteogenic potential in vitro and in vivo. J Bone Miner Res 1998;13:828838 .

23 Farrington-Rock C, Crofts NJ, Doherty MJ, Ashton BA, Griffin-Jones C, Canfield AE: Chondrogenic and adipogenic potential of microvascular pericytes. Circulation 2004; 110:2226-2232.

24 Schor AM, Canfield AE: Osteogenic potential of vascular pericytes in marrow stromal cell cultures; in Beresford JN, Owen ME (eds): Marrow Stromal Cell Culture. Cambridge, Cambridge University Press, 1998, pp 128-148.

25 Canfield AE, Doherty MJ, Wood AC, Farrington $\mathrm{C}$, Ashton $\mathrm{B}$, Begum N, Harvey $\mathrm{B}$, Poole A, Grant ME, Boot-Handford RP: Role of pericytes in vascular calcification: a review. Z Kardiol 2000;89(suppl 2):20-27.

26 Shao JS, Cai J, Towler DA: Molecular mechanisms of vascular calcification: lessons learned from the aorta. Arterioscler Thromb Vasc Biol 2006;26:1423-1430.

27 Wilkinson FL, Liu Y, Rucka AK, Jeziorska M, Hoyland JA, Heagerty AM, Canfield AE, Alexander MY: Contribution of VCAF-positive cells to neovascularization and calcification in atherosclerotic plaque development. J Pathol 2007;211:362-369.

-28 Ozerdem U, Grako KA, Dahlin-Huppe K, Monosov E, Stallcup WB: NG2 proteoglycan is expressed exclusively by mural cells during vascular morphogenesis. Dev Dyn 2001;222: 218-227.

29 Ozerdem U, Monosov E, Stallcup WB: NG2 proteoglycan expression by pericytes in pathological microvasculature. Microvasc Res 2002;63:129-134.

30 Komatsu M, Ruoslahti E: R-Ras is a global regulator of vascular regeneration that suppresses intimal hyperplasia and tumor angiogenesis. Nat Med 2005;11:1346-1350.

31 Shepro D, Morel NM: Pericyte physiology. FASEB J 1993;7:1031-1038.

- 32 Hinz B, Phan SH, Thannickal VJ, Galli A, Bochaton-Piallat ML, Gabbiani G: The myofibroblast: one function, multiple origins. Am J Pathol 2007;170:1807-1816. 
-33 Sappino AP, Schurch W, Gabbiani G: Differentiation repertoire of fibroblastic cells: expression of cytoskeletal proteins as marker of phenotypic modulations. Lab Invest 1990; 63:144-161.

-34 Schmitt-Graff A, Desmouliere A, Gabbiani G: Heterogeneity of myofibroblast phenotypic features: an example of fibroblastic cell plasticity. Virchows Arch 1994;425:3-24.

35 Zengin E, Chalajour F, Gehling UM, Ito WD, Treede H, Lauke H, Weil J, Reichenspurner H, Kilic N, Ergun S: Vascular wall resident progenitor cells: a source for postnatal vasculogenesis. Development 2006;133:15431551.

- 36 Covas DT, Panepucci RA, Fontes AM, Silva WA Jr, Orellana MD, Freitas MC, Neder L, Santos AR, Peres LC, Jamur MC, Zago MA: Multipotent mesenchymal stromal cells obtained from diverse human tissues share functional properties and gene-expression profile with CD146+ perivascular cells and fibroblasts. Exp Hematol 2008;36:642-654.

37 Maddox JR, Liao X, Li F, Niyibizi C: Effects of culturing on the stability of the putative murine adipose derived stem cells markers. Open Stem Cell J 2009;1:54-61.

38 Bu J, Akhtar N, Nishiyama A: Transient expression of the NG2 proteoglycan by a subpopulation of activated macrophages in an excitotoxic hippocampal lesion. Glia 2001; 34:296-310.

-39 Grako KA, Stallcup WB: Participation of the NG2 proteoglycan in rat aortic smooth muscle cell responses to platelet-derived growth factor. Exp Cell Res 1995;221:231-240.
40 Hellstrom M, Kalen M, Lindahl P, Abramsson A, Betsholtz C: Role of PDGF-B and PDGF-beta in recruitment of vascular smooth muscle cells and pericytes during embryonic blood vessel formation in the mouse. Development 1999;126:3047-3055.

41 Lindahl P, Bostrom H, Karlsson L, Hellstrom M, Kalen M, Betsholtz C: Role of platelet-derived growth factors in angiogenesis and al veogenesis. Curr Top Pathol 1999;93:27-33.

42 Murfee WL, Rehorn MR, Peirce SM, Skalak TC: Perivascular cells along venules upregulate NG2 expression during microvascular remodeling. Microcirculation 2006;13:261273.

43 Pacilli A, Pasquinelli G: Vascular wall resident progenitor cells: a review. Exp Cell Res 2009;315:901-914.

44 Abedin M, Tintut Y, Demer LL: Mesenchymal stem cells and the artery wall. Circ Res 2004;95:671-676.

45 Sartore S, Chiavegato A, Faggin E, Franch R, Puato M, Ausoni S, Pauletto P: Contribution of adventitial fibroblasts to neointima formation and vascular remodeling: from innocent bystander to active participant. Circ Res 2001;89:1111-1121.

46 Tintut Y, Alfonso Z, Saini T, Radcliff K, Watson K, Bostrom K, Demer LL: Multilineage potential of cells from the artery wall. Circulation 2003;108:2505-2510.

47 Zalewski A, Shi Y: Vascular myofibroblasts. Lessons from coronary repair and remodeling. Arterioscler Thromb Vasc Biol 1997;17: 417-422.

48 Huang FJ, You WK, Bonaldo P, Seyfried TN, Pasquale EB, Stallcup WB: Pericyte deficiencies lead to aberrant tumor vascularizaton in the brain of the NG2 null mouse. Dev Biol 2010;344:1035-1046.
49 Chekenya M, Krakstad C, Svendsen A, Netland IA, Staalesen V, Tysnes BB, Selheim F, Wang J, Sakariassen PO, Sandal T, Lonning PE, Flatmark T, Enger PO, Bjerkvig R, Sioud $\mathrm{M}$, Stallcup WB: The progenitor cell marker NG2/MPG promotes chemoresistance by activation of integrin-dependent PI3K/Akt signaling. Oncogene 2008;27:5182-5194.

50 Fukushi J, Makagiansar IT, Stallcup WB: NG2 proteoglycan promotes endothelial cell motility and angiogenesis via engagement of galectin-3 and alpha3beta1 integrin. Mol Biol Cell 2004;15:3580-3590.

51 Makagiansar IT, Williams S, Dahlin-Huppe K, Fukushi J, Mustelin T, Stallcup WB: Phosphorylation of NG2 proteoglycan by protein kinase $\mathrm{C}$-alpha regulates polarized membrane distribution and cell motility. J Biol Chem 2004;279:55262-55270.

52 Minasi MG, Riminucci M, De Angelis L, Borello U, Berarducci B, Innocenzi A, Caprioli A, Sirabella D, Baiocchi M, De Maria R, Boratto R, Jaffredo T, Broccoli V, Bianco P, Cossu G: The meso-angioblast: a multipotent, self-renewing cell that originates from the dorsal aorta and differentiates into most mesodermal tissues. Development 2002;129: 2773-2783.

53 Howson KM, Aplin AC, Gelati M, Alessandri G, Parati EA, Nicosia RF: The postnatal rat aorta contains pericyte progenitor cells that form spheroidal colonies in suspension culture. Am J Physiol Cell Physiol 2005; 289:C1396-C1407.

54 Corselli M, Chen CW, Sun B, Yap S, Rubin JP, Peault B: The tunica adventitia of human arteries and veins as a source of mesenchymal stem cells. Stem Cells Dev 2012;21:12991308. 